\title{
STATE IMMUNITY IN CIVIL PROCEEDINGS ${ }^{1}$
}

\section{THE SUBJECT OF THE PAPER, ITS MEANING AND SCOPE}

The problems of the dissertation concern matters of critical importance to theory and practice. The author analyzes the main theme in a thorough and comprehensive manner. The original design and the proper working methodology combined with the wide range of issues discussed, along with the rich source foundation of the study have enabled the author to draw up such a thorough dissertation on this difficult and, at the same time, current topic. This monograph is the most outstanding post-doctoral work to have been written in recent years amongst representatives of the young generation of Polish process experts.

It is P. Grzegorczyk's merit that Polish learning has been enriched with such a valuable monograph, of the highest professional level, whose

\footnotetext{
* Prof. dr hab., the head of the Department of Civil Procedure at Nicolaus Copernicus University in Torun and the head of the Chair of Substantive and Procedural Civil Law at Kazimierz Wielki University in Bydgoszcz. A founder member of the editorial board of Comparative Law Review since the moment of its coming into being and Editor-in-chief of this journal since 2013. The author of more than 160 publications, including those in the English, French, German and Italian languages. Academic interests include: civil procedure, particularly committal and enforcement proceedings, as well as, the organization and administration of justice in civil cases and comparative procedural law. A member of numerous national and international academic societies.

1 The review article of the habilitation dissertation by Pawel Grzegorczyk, Immunitet państwa w postępowaniu cywilnym [State Immunity in Civil Proceedings], Warszawa: Wolters Kluwers Polska 2010, 707 pages. Polish text of this article appeared on the pages of: Polski Proces Cywilny [Polish Civil Process] 2012, no. 2, p. 349 et seq. The English version of this article contains a few changes and supplements compared to its text in Polish.
} 
author undertakes a multi-faceted process analysis of an institution, living and still raising a lot of emotions and disputes in case law and in the European doctrine ${ }^{2}$. It is no coincidence that most of the monographs set out by the author in his dissertation devoted to the topic of this immunity were developed in recent years. These works were written primarily from the perspective of public international law, while the dissertation under review was written from the perspective of the law of civil procedure. The issues from both public international law and constitutional law are undertaken in the dissertation only to the extent in which they were found to be necessary to analyze the title issue from the point of view of process. Thus, another merit of the work is its interdisciplinary nature. It stems, firstly, from the specific nature of the institution analyzed in the work and, secondly, from the principles of research accepted by the author. Accordingly, public international law defines the bases and range of State immunity, but the execution

2 In recent years, the problems of State immunity in civil proceedings became relevant again, also in cases for redressing damage caused to nationals of States by German armed forces during the WW2, in the territories of the occupied countries. For more on the jurisdiction of foreign courts in these matters confer: Sz. Janczarek, Immunitet jurysdykcyjny państwa a bezwzględnie obowiązujące normy prawa międzynarodowego [Jurisdictional State Immunity and Absolute Standards of International Law], Państwo i Prawo [State and Law] 2009, no. 12, p. 57 et seq. and P. Grzegorczyk, supra note 1, p. 201 et seq. Also on the grounds of the Polish legal system, this problem was the subject of an exceptionally thorough and broad analysis in the decision of the Sąd Najwyższy [Supreme Court] of 29.10.2010, IV CSK 465/09, Orzecznictwo Sądu Najwyższego - Izba Cywilna [Decisions of the Supreme Court - Civil Chamber; OSNC] 2011, no. 2, item 22, in which a thesis was formulated that at the current stage of public international law development, the German State is entitled to a jurisdictional immunity in cases for claims, arising from torts committed by the German armed forces during the WW2 in the territory of Poland. This thesis was accepted by P. Grzegorczyk (idem, $W$ kwestii immunitetu państwa obcego przed sądem krajowym [The Issue of Foreign State Immunity before a National Court], Radca Prawny [Attorney at Law] 2011, no. 2, p. 81 et seq.) and in the glosses to this decision by W. Czapliński, Orzecznictwo Sądów Polskich [Decisions of Polish Courts; OSP] 2011, no. 7-8, item 82, p. 572, and M. Stürner, Polski Proces Cywilny [Polish Civil Process] 2011, no. 3, p. 158. Also by its judgment of 3.02.2012, (available online: http://www.icjcij.org/docket/index.php?p1=3\&p2=2\&case=143\&code=ai\&p3=4), the International Court of Justice in the Hague recognized that by allowing civil claims against the Federal Republic of Germany, related to the breach by the Third Reich in the period from 1943 to 1945 of the International Humanitarian Law, the Italian Republic infringed its international obligation to respect the immunity to which the Federal Republic of Germany was entitled on the grounds of the international law. This is the main thesis of the Court apart from this decision it contains a few consequential theses of a lesser importance for the case. 
of this immunity occurs in civil proceedings in which the principle of lex fori processualis is binding. For this reason, the issue of the dissertation is on the border between international law and national procedural law. The author focuses primarily on the process analysis of issues related to State immunity in civil proceedings. The legal bases of this immunity, however, encouraged the author to undertake a substantive discussion on the origins and development and the modern standard of the international law State immunity limited to the needs of the paper which - in my opinion - deserve a high score. The findings on this subject are contained in the first chapter of the work and provide a good starting point to the process analysis of the title issue.

All this taken together makes the scientific achievements of the author obtained in this work worth signalling to foreign readers in the pages of the journal edited by me, the more so, that the author for the needs of his considerations used a wide range of results, among others, of his exhaustive comparative law study. Yet, a longer pause in issuing our journal, made only now possible the publishing of this review article on the pages of its number 16 CLR.

In turn, it is obvious that the high rating of the substantive work expressed at the outset does not exclude the opinion, that in some respects the views of the author raise some criticism, while others provoke controversy.

The comments of the first type are caused already by the wording of the work title, because it could suggest, prima facie, that the author will cover all types of civil proceedings within the scope of his process considerations of State immunity in which the issue of State immunity may occur, as for instance in the proceedings to secure claims, the more so, that in the introduction on page 23 of his work, he claims that State immunity is an obstacle to "(...) conduct[ing] a procedure involving the State before a foreign court or another foreign process authority". However, in another paragraph of the work, State immunity is understood by the author "as a privilege enjoyed by the State before a foreign court in cases in which the State has the position of defendant or debtor, while the role of claimant or creditor is taken by a private entity" (p. 27). In consequence, the author limits, in fact, the scope of his deliberations to the civil process, non-litigious proceedings 
and enforcement proceedings in civil matters. He mentions only marginally injunction proceedings (to secure claims) (pp. 270, 443). Thus, from the point of view of the scope of the dissertation, the title: "The exemption of the State in court examination proceedings and in enforcement in civil matters" would be more adequate. I understand, however, that the author decided finally to a most synthetic approach to his work title. In turn, the author leaves outside the scope of his deliberations the cases in which the State initiates civil proceedings before a foreign court, acting as claimant in international law claims against another State.

Neither does the author undertake in his work a comprehensive discussion of State immunity in the context of restrictions of the right to the court and the issues combined with the discretion of the foreign State to decide on its immunity, although he draws attention to some cases of the State renouncing its privilege in civil proceedings. However, discussing on page 197 and subs. of his work the latest development trends in the field of State immunity, he aptly notes that these trends in the sphere of examination proceedings are aimed at a further tightening of the limits of the privilege in cases in which there have occurred the so-called serious violations of human rights by State functionaries in the exercise of their imperium.

However, to sum up, the limit of the scope of his dissertation accepted by the author with the arguments outlined for this purpose, deserves appreciation, the more so that an exhaustive discussion of State immunity in the context of the above issues would require, among other things, a significant expanding of the publishing framework and a much broader work.

\section{Methodology AND DESIGN OF WORK}

Regarding the methodology of the work, it is dominated by the formal and dogmatic method, generally adopted in this type of studies. In addition, the author applies in his work the historical descriptive method to present the genesis and the development of State immunity. Moreover, he uses the comparative law method in a wide range.

The source base of the work is exceptionally rich. The author has tried to exploit fully the achievements of pre-war and post-war Polish doctrine 
and jurisprudence. The rich scientific workshop of the author is reflected, among other matters, in his habilitation dissertation by the bibliography, counting 849 items and the work documentation in the form of 2077 generally extended footnotes. However, a small number of national studies on the title issues, especially after the entry into force of the presently binding Code of Civil Procedure, made the author base his findings largely on the foreign literature. The great ease with which the author discusses the literature should be also emphasized. The author generally analyzes and systematizes in his work the views of the doctrine and jurisprudence in order to develop his own position based on in-depth juridical arguments. In this way, the extensive literature and case law cited in the footnotes of the work have been subjected to the necessary analysis and evaluation for the needs of the reviewed dissertation.

In addition, the author used a wide range of public international law for the needs of his comparative law research, the texts of national laws on State immunity, especially American and British ones, and the case law of many foreign courts. He also took into account the rich achievements of international organizations and scientific institutions in the field of State immunity. In these studies, attention should be paid to an appropriate selection by the Author of comparative material (comparatum) in the form of provisions coming from the relevant norms of customary public international law, international conventions, the laws of selected European and non-European States, the case law of these countries, and unification projects prepared by international organizations and scientific institutions on State immunity in order to establish the evaluative identity, similarities, and differences between the compared institution from the perspective of public international law and national legal systems. In other words, the subjects of the author's comparative studies are not only isolated standards of procedural law, but also the case law, the customs, the doctrine, and still other factors that determine the formation and effective functioning of procedural law. So this refers both to the "law in book", and the "law in action"3. These circumstances

3 More details on the subject of process law comparative studies cf. K. Lubiński, Przedmiot komparatystyki prawa procesowego [The subject of the process law comparative studies], [in:] P. Grzegorczyk, K. Knoppek, M. Walasik (eds), Księga Jubileuszowa dedykowana 
deserve, in my opinion, to be emphasized, the more so, that in a number of relatively numerous scientific works in the field of procedural law, we are still dealing only with the mechanical tabulating of the laws in force, not always accurately matched to the needs of such research of the foreign law systems. It can be claimed that those comparisons are often made by way of free choices and associations. The authors of such works do not even undertake any attempts at identifying the sameness, finding differences and similarities of two or more systems of procedural law compared, or of their components, not to mention the evaluative findings in this regard ${ }^{4}$. Such comparative studies have, of course, nothing to do with the methodology and the functions of modern comparative law. This state is all the more worrying given that this type of comparative studies also meets the major objectives and theoretical and practical functions.

To sum up, the comparative law studies carried out by the author made possible a better cognizance and understanding, not only of the public international law and the foreign legal systems which regulate the institution of State immunity in civil proceedings, but also of the Polish legal system in this regard. As a result of such studies, new contents (comparandum) were also created, which will significantly enrich the comparative studies on procedural law.

When it comes to the work construction, the whole dissertation material, beyond the introduction, final notes and bibliography, has been divided into 7 chapters, which are subsequently titled by the author:

1) General issues on immunities in civil proceedings,

2) Sources of law in the field of State immunity, its scope and the latest development trends,

3) Legal basis and place of State immunity in Polish civil procedural law,

Profesorowi Feliksowi Zedlerowi [The Jubilee Journal Dedicated to Professor Feliks Zedler], Warszawa: Wolters Kluwer 2012, p. 1069 et seq.

4 An example of such works is the habilitation dissertation of P. Osowy, Powództwo o świadczenie [Claim for performance], Warszawa: Wydawnictwo Prawo i Praktyka Gospodarcza 2006, p. 33 et seq. with its legal comparative considerations. I have made numerous serious objections as to the methods and substance of this work in its review article. For more, confer K. Lubiński, Powództwo o świadczenie [Claim for performance], Przegląd Prawa Egzekucyjnego [The Review of the Enforcement Law] 2009, no. 7, p. 101 et seq. 
4) State immunity in light of process premises of civil procedure,

5) Process treatment of immunity,

6) Procedure involving State participation (selected issues),

7) State Immunity in European civil process law.

This construction of the work deserves to be accepted, because it enabled the author to include in the dissertation all the key issues of State immunity in civil proceedings.

\section{ASSESSMENT OF THE MAIN THREADS OF THE WORK}

Turning to the substantive assessment of the work, I agree with the vast majority of well-founded and documented views of the author. Analyzing the title theme, the author is also often forced to take a position in the most important and controversial, for decades, theoretical issues relating to civil process, such as involving its substance or process premises. It is also important that making a choice of one or another theoretical process concepts for the analysis of the title issues, the author often seeks to enrich the adopted concept by new substantive arguments of his own.

In this review, it is worth showing the richness of the issues examined by the author in the work from the perspective of diverse issues undertaken by Dr. P. Grzegorczyk in the individual sections of his work.

In the first chapter, after the necessary characteristics of the immunity in various areas of law and a clarification of terminological issues, the author went on to discuss the essence and the legal nature of judicial and enforcement immunities in the civil proceedings, both of these immunities compared to the national jurisdiction, especially after the entry into force of the Amending Law of $5^{\text {th }}$ December 2008 - On Amending the Code of Civil Procedure and certain other laws ${ }^{5}$ (p. 69 and subs.), and then to study other immunities in civil proceedings and to determine the direction of his further considerations.

Characterizing the legal status after the entry into force of the Amending Law of 2008, the author presents a broad assessment,

5 Dz. U. [Journal of Laws] No. 234, item 1571, referred to hereinafter as the 2008 Amending Law. 
with some critical notes, of the adopted solution under which from the institution of national jurisdiction, uniform up to then, of our Code of Civil Procedure, the problems of process immunities were isolated: the judicial and the enforcement ones (p. 79 et seq.). The legislature, following mainly German and Swiss law solutions in this field, assumed the separateness of these two immunities from the national jurisdiction. Without going into the details of these solutions, one can briefly say after the author that de lege lata under Polish law, the designation of court competence in civil matters takes place on two levels and with the help of two institutions: the jurisdictional authority and the national jurisdiction. The jurisdictional authority decides whether national courts are competent to decide the case from the standpoint of public international law. As to the national jurisdiction, it serves for the ultimate precise determination of cases in which "(...) the Polish court is obliged to grant legal protection owing to the adequate relationship between the case and the Polish legal system" (p. 642). Meanwhile, many legal systems, particularly those of common law, stand still on the ground of a uniform notion of national jurisdiction. Such a concept was also adopted in the European Convention on State Immunity drawn up on 16 $6^{\text {th }}$ May 1972 in Basel6, Switzerland, and in the United Nations Convention on Jurisdictional Immunity of States and Their Property adopted on $2^{\text {nd }}$ December 2004 by the UN General Assembly7. However, the author finally believes that the concept of separation of the jurisdictional authority and the national jurisdiction adopted de lege lata in the Polish law constitutes a more convenient basis for theoretical research into the judicial and enforcement immunity. It takes into account the uneven nature of the determinants so far conclusive on the national jurisdiction of the Polish courts. In my opinion, at least the first of these arguments is hardly convincing from the point of view of the legislature's withdrawal from the concept of national jurisdiction, uniform so far, in the international civil proceedings.

In turn, in the issue disputable in the Polish literature, referring to types of civil proceedings where the C.C.P. provisions on judicial

6 Referred to hereinafter as the Basel Convention.

7 Referred to hereinafter as the UN Convention. 
immunity are applicable, the author took finally the proper position, claiming that they also apply to non-litigious proceedings. The decisive argument, speaking for the correctness of this idea, in my opinion, shall be linked to recognizing in this regard the provisions of Part Four of the Code of Civil Procedure on court immunities as process provisions. For this reason, these provisions should be included within the scope of Article $13 \S 2$ C.C.P. on the appropriate application of the process rules to other types of proceedings covered by the Code. As to the terminological issues, I would raise only one reservation about the correctness of the terms used by the author on page 63 and subs. "process mode" (tryb procesowy) and "non-litigious mode" (tryb nieprocesowy) instead of the terms adopted in the Code as "the mode of process" (tryb procesu) and "the mode of non-litigious proceedings" (tryb postępowania nieprocesowego), since in this situation there is no need to create in the theory of Civil Procedure "legal text concepts" or in this case, those that are equiform meanings of terms in legal texts. However, I submit no substantive objections to other findings made by the author in this chapter. They are a good starting point for the further considerations of the author. Nonetheless, in this section, the author deliberately refrains from detailed characteristics of State immunity as an institution of public international law and from an attempt at formulating the new trends in this field. In the intention of the author, these comments have an organizing nature and do not pretend to discuss fully this topic. In my view, these comments are not only of an organizing nature, although they really are not exhaustive.

The second chapter of the work is extremely rich where the author presents a very wide range of sources of law in the field of State immunity, its scope and the latest development trends. Considerations on the subject are preceded, to the extent necessary, by historical notes on the development of the institutions of State immunity, to pass then to a detailed discussion on the treaty law in force, the work on the unification of the rules on State immunity at the international level within the framework of private institutions or under the auspices of international organizations, State immunity in the national law and the practice of foreign countries. Particularly noteworthy are, in my opinion, the author's considerations on the immunities of the State in the national law and the practice of foreign countries, which 
are an excellent starting point for an in-depth analysis of the scope of State immunity and the latest developments in the field of this immunity. The author distinguishes for the needs of his deliberations on State immunity, three groups of countries. The first one consists of states where no internal regulation has been adopted in the field of State immunity (Germany, Switzerland, Austria, the Netherlands, Spain, Italy, Sweden). The second group includes countries which have adopted separate legal regulations in the field of State immunity (USA, UK, Canada, Australia, Singapore, Pakistan). The third group consists of countries where although separate laws relating to state immunity have not been adopted, however this issue is partially regulated by law provisions (Russia, Czech Republic, Hungary, Belarus, Turkey). It results from the author's comparative law analysis that the states in which the institution of State immunity is the subject of a separate statutory regulation belong to the minority, although their number is steadily increasing.

The author analyses the issues of the legal basis and place of the immunity in Polish procedural law in details in the third chapter of his work. Poland belongs to the group of countries in which no internal law regulations have been adopted in the field of State immunity. The legislature has taken such a conscious decision both on the ground of C.C.P. of 1930, as well as of the Code currently in force. The legislature adopted an assumption that this issue is the exclusive domain of public international law, applied and developed in judicial practice. The author convincingly demonstrates in his work the relevance of the thesis of inadmissibility of deducing the legal basis of State immunity from the provisions of Articles 1114 and 1115 C.C.P. and the a fortiori inference from the rules governing the immunity of diplomatic agents.

From the standpoint of the public international law, the problem of determining the legal basis for State immunity is more complicated as Poland has never acceded to the Basel Convention nor to the UN Convention. The Basel Convention is the only currently binding international agreement which regulates in a comprehensive manner the issues of State immunity. On the other hand, so far, the UN Convention has not entered into force because of the failure to have, among others, the minimum number of ratifications. Other comments by the author are also acceptable, which refer to the fact that despite the strong 
associations between State immunity and the jurisdictional immunity enjoyed by diplomatic agents and consular officers, the provisions of the Vienna Convention on Diplomatic Relations signed in Vienna on $18^{\text {th }}$ April 19618 , of the Vienna Convention on Consular Relations signed in Vienna on 24th April 19639, and legal acts of the European Union do not constitute the basis for the first of them. In terms of questions not dealt with in international treaties and internal regulations, the basis to grant a foreign State its immunity is the customary international law.

Altogether, the author rightly concludes that the lack of any positive regulation of State immunity in the provisions of the Code cannot be considered as a basis for reasoning a contrario on the inadmissibility for a foreign State to enjoy the immunity in the Polish civil proceedings. On the contrary, no such regulation in conjunction with Article 9 of the Constitution and the decades-long continuity of the legal status pertaining thereto should be read, according to the author, "(...) as the consent of the legislature for the court to reach to the current international standard rule of State immunity at the moment of adjudicating" (p. 644), or else in this case, the norms of the international customary law ${ }^{10}$. Finally, the author comes to the conclusion, legitimate in my opinion, that the omission of the foreign State among the entities enjoying immunity under Article 1111 et seq. of C.C.P. is a constructional gap in the range of a foreign State immunity, which should be supplemented " (...) by reference to the provisions on the court and enforcement immunity, in particular, Article 1113 C.C.P., the key to the proper manner of examining and determining the process consequences of the court immunity".

\footnotetext{
8 Dz. U. [Journal of Laws] 1965, No. 37, item 232.

9 Dz. U. [Journal of Laws] 1982, No. 13, item 98.

10 This view finds its confirmation also in the judicature and in the doctrine of many States and the European Court of Human Rights. More, confer P. Grzegorczyk, supra note 1, p. 133 et seq. and the literature cited there. It is also adopted in the more recent jurisdiction of the Sąd Najwyższy [Supreme Court] that in view of no treaty and law regulations, the commonly applied customs of the international law are a source of jurisdictional immunity of a foreign State and its authorities in cases related to the authoritative activities of the State. Confer decision of the Sąd Najwyższy [Supreme Court] of 13.03.2008, III CSK 293/07, Orzecznictwo Sądu Najwyższego - Zbiór Dodatkowy [Decisions of the Supreme Court - Supplement; OSN-ZD] 2009, no. 2, item 33.
} 
The author, however, speaks against a comprehensive regulation in Polish law of the institution of State immunity by codifying or another separate law. The author justifies this view, above all, by the position in this area of the Polish legislature consistent for decades, and the international standard of State immunity still evolving and difficult to determine (p. 659). On the other hand, it is difficult not to notice that the existence of this gap in the law and its filling by analogiae legis can only suggest legal system flaws in this regard, and therefore this condition must be considered as temporary and regardless of the tradition adopted in this area by the Polish legislature. Therefore, I find fully founded and well-balanced the Author's postulate de lege ferenda on the need to introduce to the provisions of the Code of Civil Procedure, such provisions as would allow the covering of a foreign State by judicial immunity, and in addition referring as to the scope of a foreign State immunity to the norms of the customary international law (p. 660).

In general and in the analysed case, the Polish process tradition must be respected wherever possible, and wherever necessary modified or derogated from.

In turn, in the fourth chapter of the work, having first identified the notions and system of process premises, the author analyses State immunity against the background of these premises in the examination and enforcement proceedings. The author stipulates that in his deliberations there is no room for an exhaustive analysis of the concept of process premises nor for building their systematization (p. 294). In my opinion, he assumes, however, a too narrow definition of a process premise for the needs of his work. Process premises are understood by him as "(...) only such circumstances whose existence (positive premise) or non-existence (negative premise) determines the admissibility of the proceedings and rendering a decision on the merits of the case by the court seized" (p. 296). This definition of the process premise does not include even non-litigious proceedings. Meanwhile, to place the State's immunity in civil proceedings amongst process premises for this procedure, a definition of the process premises, covering the whole range of civil proceedings should have been adopted.

Turning to another issue, the author includes State immunity in the group of absolute process premises, because it is taken into account 
by the court ex officio. In the science, the issue of process premises distinguishing as relative and absolute ones depends, of course, on the adopted classification criterion. In this regard, there is no conformity of views between scholars. Classifications of premises are built on heterogeneous criteria. Thus, the author was entitled to consider, primarily, on the grounds of German and Austrian scholarly achievements that the absolute process premise is such a one, which is considered by the court of its own motion at any stage of the case ${ }^{11}$.

Many detailed process matters, relating to State immunity in examination proceedings and enforcement proceedings are discussed by the author in the fifth chapter of his work with correct factual findings in this respect. Particularly noteworthy are: the considerations on the sequence of State immunity testing against the background of process premises, on the method of process material collection, on the burden of proof, on the decision on State immunity and the consequence thereof for the later course of proceedings, and on State immunity after the decision has come into force. In the latter case, I particularly appreciate the author's comments on the annulment of a court decision of force of law at the request of the Attorney General, derived from the Austrian law and known for decades to Polish law institutions in the cases in which the court decision violates State immunity in civil proceedings.

In turn, in the sixth chapter of his work, the Author correctly solves a number of legal dogmatic issues related to the course of conduct involving a foreign State not only for the needs of practice. This refers to the judicial, process capacity and the ability to undertake independent process procedures of a foreign State, the national jurisdiction against

\footnotetext{
11 Such a criterion of separating the absolute process premise is also known in Polish scholarship. Confer on this topic in particular E. Waśkowski, Podręcznik procesu cywilnego [Manual of Civil Process], Wilno 1932, p. 198; W. Berutowicz, Postępowanie cywilne w zarysie [An outline of civil proceedings], Warszawa: PWN 1984, p. 107; H. Mądrzak (ed.), Postępowanie cywilne [Civil proceedings], Warszawa: C.H. Beck 2003, p. 31 and K. Weitz, Jurysdykcja krajowa $w$ postępowaniu cywilnym [National jurisdiction in civil proceedings], Warszawa: Prawo i Praktyka Gospodarcza 2005, p. 390. On other criteria for the division of process premises into absolute and relative ones, confer in particular W. Siedlecki, Nieważność procesu cywilnego [Invalidity of civil process], Warszawa: Wydawnictwo Prawnicze 1965, p. 71 et seq. and Z. Resich, Przestanki procesowe [Process premises], Warszawa: Wydawnictwa Prawnicze 1966, p. 96 et seq.
} 
a foreign State, writ service on a foreign State, process times, a default judgment against a foreign State, and the participation in the proceedings of non-judicial authorities of the fori State. In the latter case, the position of the author is worth noting on the issue of the prosecutor's participation as a public interest spokesman in the Polish civil proceedings in order to secure the proper decision on State immunity. The author not without reason indicates that the "case of a trial against a foreign State is probably one of the least convenient starting points for reflections on the position of prosecutor in the civil process" (p. 579) against the background of a strong criticism in the literature broadly outlining the powers of the prosecutor to initiate civil actions on behalf of other persons without their consent. This criticism is shared by the author, but justified in my opinion. The prosecutor joining these proceedings pursuant to Article 60 C.C.P., in conjunction with the Attorney General's authority to initiate the cassation appeal in these matters, may indeed be an appropriate measure for reducing the risk of international responsibility involved by the breach of jurisdictional immunity. However, in my opinion, for the purpose of civil procedure codification, the need to adopt the principle of closed number enumeration shall be considered, to allow the prosecutor to bring an action only in cases prescribed by law. This would encompass civil cases in which there are strong features of public interest. However, when speaking of the prosecutor joining the pending proceedings in order to protect this interest, the legislature could consider the adoption of the principle of the general limited clause.

Also rich are the issues of the last chapter of the work, in which the author carefully examines quite a range of problems related to State immunity in European civil procedural law, including in the scope of his considerations three such complexes of essential issues: a) the application of the European civil procedure law in cases involving foreign States participation b) the associations and relationship between the provisions of the European civil procedure law, establishing the jurisdiction of the Member States and the national standards on State immunity, c) State immunity and the recognition and enforcement of foreign decisions. In this chapter, the author's considerations are also at the highest level of substantial expertise, and his findings deserve appreciation. 
The author undertakes a successful attempt to summarize his detailed and rich considerations in the conclusions of his work.

\section{CONCLUSIONS}

In the conclusion of this article, it should be noted that the habilitation dissertation of Mr P. Grzegorczyk is an outstanding work, providing evidence of the exceptional scientific competence of the author. It is a significant contribution to the development of the science of civil procedure not limited only to Polish scholarship. In consequence, we can recommend the author to take the trouble to prepare, on the basis of this work, foreign language publications, to approximate to the foreign studies, the scientific achievements of the author, arising from this work of his, the more so that this dissertation does not include even a short summary in a language other than the Polish language. 
